This is not the version of record. The full version of Umar, Tariq (2018) Briefing : Towards a sustainable energy : the potential of biomass for electricity generation in Oman. Proceedings of the Institution of Civil Engineers Engineering Sustainability, 171(7), pp. 329-333 can be found at https://doi.org/10.1680/jensu.17.00001 


\title{
Towards a Sustainable Energy; The Potential of Biomass for Electricity Generation in Oman.
}

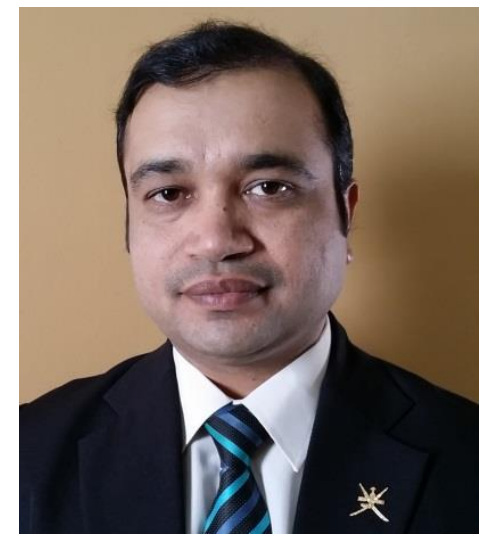

\author{
Tariq Umar MSc, CEng MICE, PhD Candidate, London South Bank \\ University/ \\ College of engineering, A'Sharqiyah University, Oman \\ E-mail: tariqumar1984@gmail.com
}

\begin{abstract}
:
Oman, like other Arab gulf countries, depends on oil and gas to produce electricity. However, these resources are not guaranteed to last forever and constitute one of the energy security issues in the country. This article explores the potential of using biomass energy resources for electricity generation in Oman. Energy from biomass resources is counted as a type of renewable energy, which means the availability is not affected by the lack of source and the increasing price of fossil oil. The review of biomass energy shows that waste from different sources such as wood and woody plants and their wastes, agricultural crops and residues, municipal solid organic wastes, animal wastes, sewage, waste from organic industrial processing and food processing, and aquatic plants and algae can be used for electrify generation. The biomass from animal manure and wastewater are reported with its potential for electricity generation. The results show that a total of $2651.81 \mathrm{GWh}$ per year electricity can be produced from animal manure and wastewater which corresponds to $10 \%$ of the total electricity consumption in Oman. Although there is potential to use biomass for a sustainable electricity generation, however several environmental, social and technological factors associated with biomass energy need to be considered before adopting such resources.
\end{abstract}

Keywords: Energy, Sustainability, Waste management \& disposal, Renewable energy

\section{Introduction:}

Energy is essential to economic and social development and improved quality of life in all countries. Problems with conventional energy are that it produces greenhouse gases which affect climate and can't sustain for long time. It is essential to tackle these problems by moving towards sustainable energy. Oman's economy is heavily reliant on oil and gas revenues, which accounted for about $84 \%$ in 2014 of the country's export earnings and $47.2 \%$ of its gross domestic product (CBO, 2015, NCSI, 2015). All of Oman's domestic energy consumption is supplied by natural gas and oil, reflecting the country's relative abundance of oil and natural gas reserves. In 2011, oil accounted for $71 \%$ of Oman's total primary energy consumption, and natural gas made up the remaining $29 \%$. With the exception of 2009, Oman's petroleum 
consumption rose steadily over the past decade, reaching 154,000 barrels/day in 2013. This further has a significant contribution towards greenhouses gases.

Oman, like other Arab gulf countries, depends on oil and gas to produce electricity. However, these resources are not guaranteed to last forever, and are one of the energy security issues in the country. Some of the gulf countries have diversified their energy resources for example, the Emirates has considered nuclear and renewable energy as part of their electric generation and Qatar aims to generate $20 \%$ of its energy from renewables by 2024 with $1800 \mathrm{MW}$ of installed green capacity by 2020. As for Oman, the progress of renewable energy development is at a slow pace as currently the electricity generation is still dependent on oil and gas. Omani Vision 2020 seeks to reduce dependence on oil, diversify the economy and create new employment opportunities for all citizens. Omani Vision 2020 also stresses on the promotion of technology transfer and the increased use of natural and renewable resources, with due regard to the social and natural environment, which gives priority to the main key aspects (NCSI, 2008).

In the last two decades energy consumption in the Gulf Cooperation Council (GCC) member countries (Bahrain, Kuwait, Oman, Qatar, Saudi Arab and United Arab Emirates) has increased rapidly. In 2013, the average electricity consumption in GCC countries was approximately $12370.91 \mathrm{kWh}$ per year per capita while in China this value was 3762.07 (WB, 2016). GCC countries electricity consumption is more than double of the consumption per capita in United Kingdom, which is $5407.29 \mathrm{kWh}$. In 2013, the electricity consumption per capita in Oman was $5981.45 \mathrm{kWh}$. The main reasons for the high consumption rate of electricity in GCC countries is high temperature in summer and secondly the cost of electricity is very low compared to other countries. The low cost of electricity for both domestic and industrial users in GCC countries don't encourage them to avoid the excessive use of electricity. In Oman, the electricity consumption is comparatively low than other GCC countries as Oman is somehow beyond in terms of infrastructures development and industrialization.

Umar and Wamuziri (2016) explore the potential of wind and solar energy in Oman and found that there is a huge opportunity to use these resources. Since ancient times biomass has played an important role in the society, and is nowadays used as fuel in a wide range of applications, such as cooking, heating and power generation. Biomass can be converted into electric power through several methods. Heat is used to thermos chemically convert biomass into a fuel oil which is then burned like petroleum to generate electricity. Biomass can also be burned directly to produce steam for electricity production or manufacturing processes. One alternative for producing electricity from biomass in a gas turbine is direct combustion of biomass as a primary energy source. Biomass is burned directly to produce steam, the steam turns a turbine which derives a generator thus electricity is generated. The aim of this paper is to make an assessment of the potential in biomass resources available in Oman and discuss this potential with respect to the expected long-term sustainable energy needs of the country. It is estimated that Oman can produce 2604.44 GWh from animal manure and 47.37 GWh from wastewater treatment. 


\section{Literature Review:}

In September 2015, the 193 United Nation (UN) member states adopted the new Sustainable Development Goals (SDGs) consisting of 17 goals, supported by 169 targets and underpinned by 230 global indicators. Access to affordable, reliable, sustainable and modern energy for all is one of the UN sustainable goals set for achievement by 2030 (UN SDGs, 2015). Energy from solar, wind, geothermal, biomass, waves and tidal are some of the sustainable resources of the energy adopted in different regions. In the year 2010, renewable energy sources accounted for an estimated $16.7 \%$ of global final energy consumption, while traditional biomass accounted for $8.5 \%$ of total energy consumption globally (EUI, 2013). It is projected that electricity generation from different renewable resources will be more than 10 trillion kilowatt-hours by 2040 (EIA, 2016). Biomass resources include wood and woody plants and their wastes, agricultural crops and residues, municipal solid organic wastes, animal wastes, sewage, waste from organic industrial processing and food processing, and aquatic plants and algae. The use of biomass to produce electricity has steadily increased by an average of 13 TWh per year between 2000 and 2008. Biomass based electricity has maintained its market share of total global generation over the last 20 years, at approximately 2\% (Strezov. and Evans, 2010). Statistics from International Energy Agency indicates that a total of 370 TWh of bioenergy electricity was produced in 2012, which corresponds to $1.5 \%$ of world electricity generation (IEA, 2016).

A recent conducted by Hamamre et al. (2017), on sustainable-renewable energy resources for Jordan shows that Jordan has an annual power potential 847.39 GWh from different types biomass. In the last decade, many new biomass power plants have been built and the development of new technologies for biomass-based power generation is going on. Figure 1 shows the integrated biomass gas turbine/steam combined cycle power plant (Alidrisi, and Demirbas, 2016). 


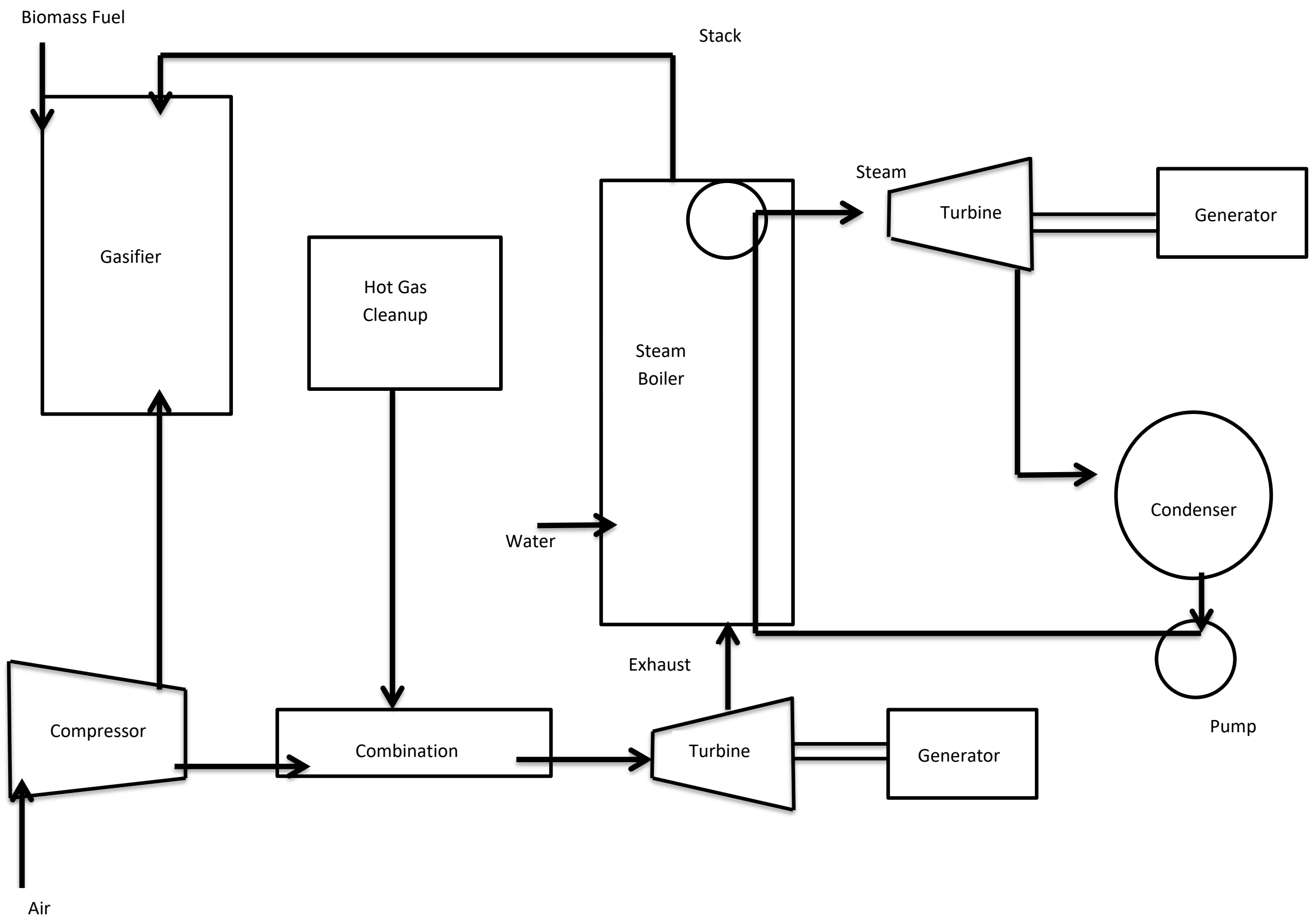

Figure 1. Integrated biomass gas turbine/steam combined cycle power plant (Alidrisi, and Demirbas, 2016) 
There are three primary technology categories (Pyrolysis, Gasification and Direct combustion) used for the combustion based conversion of biomass into electricity. Each category has undergone significant development and therefore has many different methods available. A simple biomass electric generation system is made up of several key components. For a steam cycle, this includes a combination of the following items:

(i) fuel storage and handling equipment, (ii) gasfier, (iii) combustor/furnace, (iv) boiler, (v) pumps, (vi) fans (vii) steam turbine, (viii) generator, (ix) condenser, (x) cooling tower, (xi) exhaust/emissions controls, and (xii) system controls (automated).

The generation of electricity from biomass faces various environmental, technological and social challenges. Electricity price, efficiencies, greenhouse gas emissions, availability and limitations for biomass produced electricity are currently favourable, when compared with the other energy generation options, however, significant attention must be given to reducing the land and water use and, the social impacts of biomass power generation before sustainability can be achieved (Evans et al. 2010).

\section{Biomass Energy Potential in Oman:}

Although biomass from different sources are available in Oman, however the two of them i.e., animal waste and waste from water treatment are discussed here.

\subsection{Biomass Energy from Animal Manure:}

The history of Oman reflects that it has had a variety of useful animals while sheep and cattle farming was one of the main traditional occupations of the peoples. This occupation was supported by the large area available for agricultural purpose and by the historic system of irrigation. Dhofar region of Oman, which is one of the largest of the eleven Governorates in the Oman in terms of area, is more supportive to this occupation due to its green climate. The occupation is now covered under the ministry of Ministry of Fisheries and Agriculture in Oman. The wide diversity of animal genetic resources in Oman includes cattle, sheep and goats, poultry and camels. For the number of different animals the Ministry of Fisheries and Agriculture in Oman is used in this research. The total number of animals in 2014 stood at 547,713 for cows, 273,203 (camels), 311,1569 (goats), and 102,6395 (sheep) respectively (MAF, 2014). Table 1 shows the number of different types of animal in different regions of Oman. 


\begin{tabular}{|l|c|c|c|c|}
\hline Region & Cows & Camels & Goats & Sheep \\
\hline Muscat & 5492 & 525 & 77809 & 23258 \\
\hline Dhofar & 207891 & 151571 & 283689 & 15105 \\
\hline Musandam & 333 & 21 & 127985 & 13399 \\
\hline Al Buraimi & 5890 & 4395 & 85019 & 39792 \\
\hline Al Dakhilia & 18063 & 11537 & 229180 & 59573 \\
\hline Al Batinah North & 67119 & 11003 & 351717 & 136996 \\
\hline Al Batinah South & 23113 & 9114 & 157379 & 51388 \\
\hline $\begin{array}{l}\text { Al Sharqiyah } \\
\text { South Sharqiyah }\end{array}$ & 9260 & 20375 & 312986 & 78575 \\
\hline $\begin{array}{l}\text { Al North } \\
\text { Nor }\end{array}$ & 8431 & 24592 & 250356 & 76129 \\
\hline Al Dhahirah & 13914 & 6938 & 169548 & 65135 \\
\hline Al Wusta & 1 & 20810 & 104245 & 22237 \\
\hline Imported & 188206 & 12322 & 961656 & 444808 \\
\hline Total & $\mathbf{5 4 7 7 1 3}$ & $\mathbf{2 7 3 2 0 3}$ & $\mathbf{3 1 1 1 5 6 9}$ & $\mathbf{1 0 2 6 3 9 5}$ \\
\hline
\end{tabular}

Table 1: Number of Animals in Different Regions of Oman (MAF, 2014)

According to Monteiro et al. (2011) the Manure or the total solids (TS) are estimated per year for different types of animal considering the average value of $5.5 \mathrm{~kg} /$ day for cows, $4.16 \mathrm{~kg} / \mathrm{day}$ for camels, and $0.5 \mathrm{~kg} / \mathrm{per}$ day for goats and sheep. The volatile solid (VS) in each category is obtained by multiplying 0.75 to total solid as shown in table 2 . An average value for the weight of each type of animal is considered for this calculation.

\begin{tabular}{|c|c|c|c|c|}
\hline Types of Animals & $\begin{array}{c}\text { Cows } \\
(250 \mathrm{~kg})\end{array}$ & $\begin{array}{l}\text { Camels } \\
(250 \mathrm{~kg})\end{array}$ & Goats (25 kg) & Sheep $(30 \mathrm{~kg})$ \\
\hline Total number & 547713 & 273203 & 3111569 & 1026395 \\
\hline $\begin{array}{l}\text { Manure - Total } \\
\text { Solids (TS) tonnes } \\
\text { / } \\
\text { year per animal }\end{array}$ & $\begin{array}{l}5.5 \times 30 \times 12 \\
/ 1000=\mathbf{1 . 9 8}\end{array}$ & $\begin{array}{c}4.16 \times 30 \times \\
12 / 1000= \\
\mathbf{1 . 5 0}\end{array}$ & $\begin{array}{c}0.5 \times 30 \times 12 / \\
1000=\mathbf{0 . 1 8}\end{array}$ & $\begin{array}{c}0.5 \times 30 \times 12 / \\
1000=\mathbf{0 . 1 8}\end{array}$ \\
\hline $\begin{array}{l}\text { Total TS tonnes / } \\
\text { year }\end{array}$ & $\begin{array}{l}1.98 \times 547713 \\
=\mathbf{1 0 8 4 4 7 1 . 7 4}\end{array}$ & $\begin{array}{c}1.5 \times 273203 \\
=\mathbf{4 0 9 8 0 4 . 5}\end{array}$ & $\begin{array}{c}0.18 x \\
3111569= \\
\mathbf{5 6 0 0 8 2 . 4 3}\end{array}$ & $\begin{array}{c}0.18 x \\
1026395= \\
\mathbf{1 8 4 7 5 1 . 1 0}\end{array}$ \\
\hline \begin{tabular}{ll} 
VS & \multicolumn{2}{c}{ (Volatile } \\
Solids) & tonnes / \\
year &
\end{tabular} & $\begin{array}{c}0.75 x \\
1084471.74= \\
\mathbf{8 1 3 3 5 3 . 8 0}\end{array}$ & $\begin{array}{c}0.75 x \\
409804.5= \\
\mathbf{3 0 7 3 5 3 . 3 7}\end{array}$ & $\begin{array}{c}0.75 x \\
560082.43= \\
\mathbf{4 2 0 0 6 1 . 8 2}\end{array}$ & $\begin{array}{c}0.75 x \\
184751.10= \\
\mathbf{1 3 8 5 6 3 . 3 2}\end{array}$ \\
\hline $\begin{array}{l}\text { Total VS tonnes / } \\
\text { year }\end{array}$ & \multicolumn{4}{|c|}{ 1679332.32 } \\
\hline
\end{tabular}

Table 2: Calculation of Total Volatile Solids from Manure of Different Animal 
Research conducted by Monteiro et al (2011) shows that biogas production is $0.33 \mathrm{~m}^{3} / \mathrm{kg}$ from animal Volatile Solids. Widyastuti et al (2013) reported that $4.7 \mathrm{kWh}$ of electricity could be produced by $1 \mathrm{~m}^{3}$ biogas. Thus the potential of biogas production and electricity generation per year from animal manure listed in table 2 is as under:

Biogas production $=1679332.32 \times 1000 \times 0.33=\mathbf{5 5 4 1 7 9 6 6 5 . 6} \mathbf{~ m}^{3} /$ year

Electricity Production $=554179665.6$ x $4.7=\mathbf{2 6 0 4 6 4 4 4 2 2 8 . 3 2} \mathbf{k W h}$ or 2604.44 GWh

\subsection{Biomass Energy from Wastewater Treatment (Sludge):}

Responsibility for Oman's wastewater sector is divided among five entities with each having a different geographic jurisdiction. They are:

a) Haya Water oversees wastewater services in the Muscat governorate.

b) Salalah Sanitary Drainage Services Company (SSDSC) looks after Salalah city, and some part of the Dhofar governorate.

c) Dhofar Municipality has responsibility for the rest of the Dhofar region.

d) Sohar Development Office within Muscat Municipality looks after the Sohar province.

e) The Regional Municipalities \& Water Resources Ministry has responsibility for the rest of Oman.

In addition to the wastewater treatment plants and networks owned and operated by the five public entities, hundreds of smaller plants are also owned by the private sector. The total wastewater treatment capacity in 2008 was $105,990 \mathrm{~m}^{3} /$ day (figure 2) and it was estimated that $230,000 \mathrm{~m}^{3} /$ day (MEED, 2008). Thus the total capacity for wastewater treatment by the end of 2016 is estimated $335,990 \mathrm{~m}^{3} /$ day.

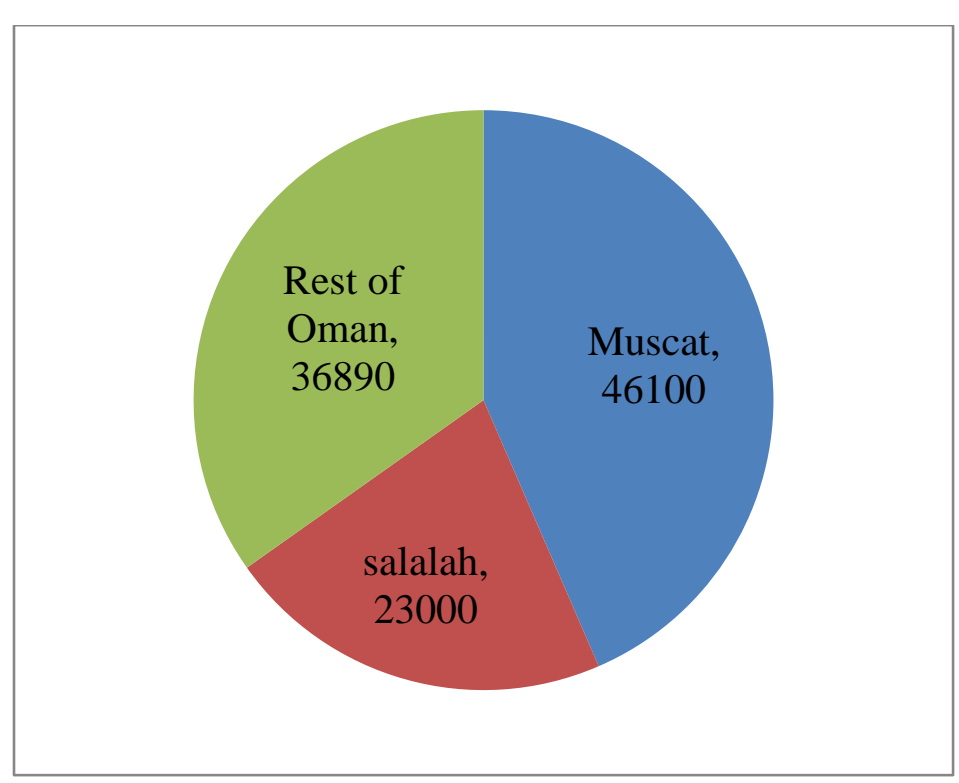

Figure 2: Capacity of Wastewater Treatment $\left(\mathrm{m}^{3} / \mathrm{day}\right)$ in Oman (2008) 
Typical primary and secondary wastewater treatment produces a total of about $1.95 \mathrm{lbs}(0.94 \mathrm{~kg})$ of dry solids per 1,000 gal $\left(3.78 \mathrm{~m}^{3}\right)$ of wastewater treated (Metcalf and Eddy, 1991). Thus the quantity of sludge for one $\mathrm{m}^{3}$ can be translated as $0.25 \mathrm{~kg}$. Under optimum digestion conditions, biogas yield of $315-400 \mathrm{~m}^{3} /$ tones organic dry matter can be expected (Hanjie, 2010). A simple principle is that one third of the solid matter in the sludge can be transformed into biogas which is equivalent to about 50\% of the organic matter (IEA Bioenergy, 2015). Using this criterion, the electricity production from wastewater in Oman can be $47.37 \mathrm{GWh}$ as shown below.

Amount of treated wastewater $=335,990 \mathrm{~m}^{3} /$ day

Production of sludge from treated wastewater $=0.25 \times 335,990=83997.5 \mathrm{~m}^{3} /$ day

Biogas Production from sludge $=83997.5 \times 1 / 3=27999.16 \mathrm{~m}^{3} /$ day

Biogas Production per year $=27999.16 \times 30 \times 12=10079697.6 \mathrm{~m}^{3} /$ year

Electricity Production per year $\left(4.7 \mathrm{kWh} / 1 \mathrm{~m}^{3}\right)=10079697.6 \mathrm{x} 4.7=47374578.72 \mathrm{kWh}$ or

\section{$=47.37 \mathrm{GWh}$}

The total electricity production from animal manure and wastewater treatment is about 2651.81 GWh. Statistics from National Centre for Statistic and Information (NCSI, 2016) indicates that the total population of Oman at the end of 216 was 4,548,856 and electricity consumption is $5981.45 \mathrm{kWh}$. Thus the total electricity demand in Oman is around $27208.75 \mathrm{GWh}$. The waste from two sources (animal and wastewater) consider in this article can constitute up to $10 \%$ of the total electricity requirement in the country. Considering the use of biomass from other sources will not only increase the electricity production but will a more sustainable waste management.

The generation of electricity from biomass faces various environmental, technological and social challenges. Electricity price, efficiencies, greenhouse gas emissions, availability and limitations for biomass produced electricity needs, to be compared with the other energy generation options. Apart from this, significant attention must be given to reducing the land and water use and, the social impacts of biomass power generation before sustainability can be achieved (Evans et al 2014). The cost of electricity production from biomass is cheaper than photovoltaics, approximately equal with geothermal but more expensive than wind and hydro (Evans et al 2009).

The production of biogas from different waste is the key to enhance the electricity production. The research work conducted by Palaniswamy et al (2016) on production of biogas from kitchen waste mixed with the cow manure using an artificial neural network. The results of their research show that the highest biogas performance level of $375 \mathrm{ml} / \mathrm{g}$ volatile solids on the 25th day of digestion was achieved by a substrate profile of $80 \%$ food waste and $20 \%$ cow dung at a temperature range of $30-40^{\circ} \mathrm{C}$. 


\section{Conclusion:}

Oman like other gulf countries produces electricity from oil and gas resources which are no longer lasting and sustainable. Oil and gas reserve of Oman are low compared to other GCC countries, therefore it is essential for the country to move towards sustainable energy resources. Different research studies show that Oman can utilize the renewable energy resources from solar, wind and geothermal for electricity generation. This article provides an assessment of using biomass from two sources (animal manure and wastewater) for electricity generation. Biogas production from selected animal manure (cow, camel, goats and sheep) is estimated up to $554179665.6 \mathrm{~m}^{3}$ / year which can produce $2604.44 \mathrm{GWh}$ electricity. The treated wastewater is estimates as $335,990 \mathrm{~m}^{3}$ / day which have an electricity generation capacity of $47.37 \mathrm{GWh}$. There are several environmental, social and technological factors associated with electricity generation from biomass need to be considered before adopting such resources. Different research has shown that electricity generation from biomass is expensive from some form of renewable energy resources. Further research needs to be conducted to evaluate the total quantity of biomass from all sources in Oman and corresponding electricity production. A full feasibility need to be carried out to evaluate to cost effective sources for electricity generation among different available renewable energy resources in Oman.

\section{References:}

Al-Hamamre, Z., Saidan, M., Hararah, M., Rawajfeh, K., Alkhasawneh, H.E. and Al-Shannag, M., 2017. Wastes and biomass materials as sustainable-renewable energy resources for Jordan. Renewable and Sustainable Energy Reviews, 67(1): pp.295-314.

Alidrisi, H. and Demirbas, A., 2016. Enhanced electricity generation using biomass materials. Energy Sources, Part A: Recovery, Utilization, and Environmental Effects, 38(10): pp.14191427.

CBO (Central Bank of Oman) (2015) Annual Report 2014. Central Bank of Oman, Muscat, Oman.

EIA, 2016. (Energy Information Administration). International Energy Outlook 2016. Washington, United States. See: http://www.eia.gov/outlooks/ieo/pdf/0484(2016).pdf (accessed 29/12/2016).

EUI, 2013. (Eromonitor International). Special Report: Renewables to Become Indispensable in Future Global Energy Mix. London, United Kingdom. See: http://blog.euromonitor.com/2013/07/special-report-renewables-to-become-indispensable-infuture-global-energy-mix.html (accessed 29/12/2016) 
Evans, A., Strezov, V. and Evans, T.J., 2009. Assessment of sustainability indicators for renewable energy technologies. Renewable and sustainable energy reviews, 13(5): pp.10821088.

Evans, A., Strezov, V. and Evans, T.J., 2010. Sustainability considerations for electricity generation from biomass. Renewable and Sustainable Energy Reviews, 14(5): pp.1419-1427.

Evans, A., Strezov, V. and Evans, T.J., 2014. Sustainability Considerations for Electricity Generation from Biomass. Biomass Processing Technologies, p.33.

Hanjie, Z., 2010. Sludge treatment to increase biogas production. Skolan för arkitektur och samhällsbyggnad, Kungliga Tekniska högskolan.

https://www.iea-biogas.net/files/daten-

redaktion/download/Technical\%20Brochures/Wastewater_biogas_grey_web-1.pdf (accessed $31 / 12 / 2016)$

IEA, 2016. (International Energy Agency), "Bioenergy". Paris, France. See: https://www.iea.org/topics/renewables/subtopics/bioenergy/ (accessed 30/12/2016).

IEA, Bioenergy 2015. (International Energy Association). Sustainable biogas production in municipal wastewater treatment plants. IEA, Bioenergy 2015. Switzerland. See:

MAF, 2014. (Ministry of Fisheries and Agriculture, Oman). Second Country Report on the State of Farm Animal Genetic Resources. Ministry of Fisheries and Agriculture, Muscat, Oman.

MEED, 2008. (Middle East Business Intelligence). Wastewater Treatment in Oman. London, United Kingdom. See: https://www.meed.com/Journals/1/Files/2010/1/28/Wastewater.pdf (accessed 30/12/2016).

Metcalf and Eddy, Incorporated. 1991. Wastewater Engineering: Treatment Disposal and Reuse. New York: McGraw-Hill.

Monteiro, E., Mantha, V. and Rouboa, A., 2011. Prospective application of farm cattle manure for bioenergy production in Portugal. Renewable Energy, 36(2): pp.627-631.

NCSI (2015) Statistical Year Book. National Center for Statistic and Information, Muscat, Oman.

NCSI (National Center for Statistic and Information) (2008). The development experience and investment climate, 6th edn. National Center for Statistic and Information, Muscat, Oman.

NCSI, 2016. (National Centre for Statistics and Information). Population Clock, NCSI, 2016. Muscat, Oman. See: https://www.ncsi.gov.om/aboutus/Pages/PopulationClock.aspx (accessed 31/12/2016). 
Palaniswamy, D., Ramesh, G., Sivasankaran, S. and Kathiravan, N., (2016). Optimising biogas from food waste using a neural network model. Proceedings of the Institution of Civil EngineersMunicipal Engineer: DOI: 10.1680/jmuen.16.00008

Umar, T and Wamuziri, S (2016). Conventional, wind and solar energy resources in Oman. Proceedings of the Institutions of Civil Engineers: Energy, 169(4): 143-147

UN SDGs, 2015. (United National "Sustainable Development Goals for 2030"). New York, United States. See: https://sustainabledevelopment.un.org/?menu=1300 (accessed 29/12/2016).

WB (World Bank) (2016) Data: Electric Power Consumption (kWh per capita). World Bank, Washinton DC, USA. See:

http://data.worldbank.org/indicator/EG.USE.ELEC.KH.PC?view=chart (accessed 10/08/2016).

Widyastuti, F.R.; Purwanto; and Hadiyanto (2013). Biogas potential from the treatment of solid waste of dairy cattle: case study at Bangka botanical garden Pangkalpinang. International Journal of Waste Resources, 3(2): 1-4. 